\title{
Nobres vagabundos: a malandragem entre a adesão e a resistência ao trabalhismo durante o Estado Novo
}

Noble vagabonds: the malandragem between adherence and resistance to labourism during "Estado Novo"

Bruno Vinícius Leite de Morais*

\section{Paranhos, Adalberto}

Os desafinados: sambas e bambas no "Estado Novo"

Prefácio de Maria Izilda S. Matos

São Paulo: Intermeios; CNPq; Fapemig, 2015. 202p.

Dei um pulo na cidade.

Iaiá, minha preta, se eu sei não iria.

Só vi sacanagem, só vi covardia

Não sei como pode alguém lá viver

Quando vi o salário

Que o pobre operário

Sustenta a família

Fiquei assustado, Iaiá, minha filha, Montei no cavalo e voltei pra você.

Quando eu contar, Iaiá Serginho Meriti/Beto Sem Braço

A prática docente e a de pesquisa acadêmica encontram, entre muitas proximidades, a comum dificuldade em agregar elementos, documentos e fontes que permitam oferecer uma leitura do passado capaz de estimular interpretações de experiências e expectativas de sujeitos geralmente esquecidos, silenciados na memória oficial e no relato historiográfico predominante. $\mathrm{O}$ objetivo de narrar uma "história de baixo para cima", embora estimule o fazer

* Graduado e mestre em História e Culturas Políticas pela Faculdade de Filosofia e Ciências Humanas da Universidade Federal de Minas Gerais (UFMG). Belo Horizonte, MG, Brasil. bruno viniciusdemorais@hotmail.com 
historiográfico desde a primeira metade do século XX, ainda exige muito esforço, criatividade e perspicácia para que se identifique o eco de vozes então abafadas pelo discurso hegemônico. O esforço em captar a repercussão das palavras de grupos dissonantes em um contexto autoritário e comumente identificado como onipotente, o Estado Novo Varguista, é o que move o historiador Adalberto Paranhos nesta nova obra, produção cara a iniciados nos estudos do período e, por sua linguagem acessível, também a demais interessados. Obra para ser lida e escutada, enriquece o material disponível para pesquisadores e docentes.

Reprodução integral da tese de doutorado em História Social defendida na PUC-SP em 2005 - "praticamente sem tirar nem pôr", confessa o historiador (p.21) -, a obra constitui um novo olhar sobre o contexto e tema que o autor pesquisou no mestrado em Ciências Políticas, trabalho publicado sob o título de O roubo da fala: origens da ideologia do trabalhismo no Brasil pela Boitempo Editorial, em 1999.

Esse caminho de formação levou-o a analisar, no doutorado, discursos que não estavam afinados com a ideologia trabalhista propagada durante o primeiro governo Vargas - e, especialmente, na ditadura do Estado Novo conforme expresso no título do livro. Para encontrar essas vozes dissonantes, abafadas na interpretação recorrente, Paranhos treinou seus ouvidos para identificar os indícios espalhados pelo rico universo dos fonogramas, evidenciando a atenção do historiador ao ensinamento do linguista Luiz Tatit, em seu $O$ século da canção, de que "o canto sempre foi uma dimensão potencializada da fala” (Cotia: Ateliê Editorial, 2004, p.41).

O uso da música popular como fonte e objeto da historiografia brasileira no estudo da Era Vargas, conforme pontua o autor já na introdução do livro, remete ao ano de 1980. Quando Paranhos defendeu sua tese, em 2005, portanto, o campo organizava-se havia 25 anos. No atual contexto de publicação do trabalho, sob a forma do livro em análise nesta resenha, podemos dizer que a atenção à canção já está longe de seus primeiros passos, encontrando certa maturidade interpretativa. Contudo, o historiador identificou nessa produção acadêmica a interpretação corriqueira de uma irrestrita adesão ao discurso trabalhista do regime após a imposição do Estado Novo, em 1937, por parte dos compositores populares - focada nos sambistas cariocas. A celebração da malandragem e do estilo de vida "vadio", temas caros à tradição sambista que 
chegava aos rádios e lojas de discos de até então, estaria soterrada pelo onipotente poder do Estado. O samba se tornaria, assim, caixa de ressonância do discurso estatal, por força da real adesão ou do rolo compressor do Departamento de Imprensa e Propaganda (DIP).

Desconfiado de todo discurso social homogeneizante, como de praxe entre profissionais da pesquisa histórica, Paranhos buscou no sugestivo acervo de canções registradas em disco a persistência da malandragem e da ojeriza ao trabalho no período de vigência do DIP, entre 1939 e 1945. A intenção do autor e sua premissa básica estão nítidas em toda a redação do livro. Podemos resgatar, como síntese de seu argumento, a última frase do capítulo final: "Nesse jogo de poderes e contrapoderes, nenhuma vontade se impôs de modo absoluto, e os próprios vencedores tiveram que fazer concessões e amargar algumas derrotas, aqui ou ali” (p.137). Ou seja, o Estado operava com força sedutora e repressiva, em sua política cultural, no entanto, os populares encontravam ou forçavam brechas de expressão.

Uma vista geral e panorâmica da obra identifica três capítulos bem demarcados. No primeiro, há um balanço crítico e teórico da historiografia sobre o Estado Novo e das correntes de interpretação sobre a ação do Estado, bem como da atuação popular, as quais o autor ora corrobora, ora contesta. Conforme sua interpretação, permitindo um caminhar mais atento pela estrada que explicita "o cerco do silêncio" imposto por um Estado autoritário, é possível encontrar nas margens, nas esquinas, "vozes do coro" que destoam da partitura. Opondo-se à concepção da possibilidade real de um estado totalitário, Paranhos enfatiza a existência de conflitos e contradições, inserindo um debate introdutório na temática sobre hegemonia e dominação ideológica. Se a sua orientação teórica demonstra que nenhuma dominação ou hegemonia é total, a leitura dos cânones da historiografia sobre o período de atuação do DIP apresenta um Estado onipotente e uma voz operária a ele consonante ou por ele eclipsada. Essa discussão teórica, como é amplamente perceptível, embora breve, fornece estímulos úteis a leitores interessados na relação entre sociedade e Estado para outros contextos autoritários.

Orientados pela exposição do estado da arte, somos apresentados, no segundo capítulo, ao cenário que possibilitou a afirmação social do samba como símbolo nacional brasileiro, em meio à reelaboração da identidade nacional no contexto político pós-1930. Partindo dos debates estéticos entre 
as vertentes de samba em disputa nos primórdios da indústria fonográfica carioca e sua configuração como veículo de brasilidade, embrenhamo-nos nas relações do samba com o Estado, entre cooptação e resistência. O argumento é simples - e não menos importante por isso: a oposição à malandragem, ou, ao menos, a incerteza quanto a ela, presente em alguns sambas, não é criação do Estado Novo, sendo identificada desde os anos 1920. Algo que qualquer ouvinte das gravações do período, se minimamente atento, sabe muito bem, mas, por vezes, algumas obras sobre o período esquecem-se de mencionar.

Traçado esse caminho, no terceiro e último capítulo do livro/tese é que enfim encontramos o desenvolvimento da argumentação prometida, expondo ou juntando nos fragmentos disponíveis, indícios da persistência da malandragem e a oposição ao trabalho regular, pelo "eco de antigas palavras" veiculadas em canções. A ausência de documentação oficial do DIP, disponível para consulta, foi compensada pelo autor na ênfase sobre o documento canção registrado no fonograma, em metodologia de análise que concedia igual importância à leitura da letra e à escuta do registro; ou seja, a performance registrada em disco por vezes indiciava uma mensagem diferente, ou mesmo oposta, em canção que, à primeira vista, vangloriava o trabalho. A consolidada orientação disciplinar de fazer novas perguntas a um documento anteriormente trabalhado é aplicada às canções.

A obra de Paranhos demonstra uma oposição à retórica da ideologia trabalhista varguista não por uma natureza de concepção política stricto sensu, de indivíduos contrapostos ao modelo de Estado vigente e inseridos em uma disputa por uma concepção alternativa. Não é o "poder de Estado" que está em questão, mas os meandros do universo cotidiano. A contraposição entre malandragem e trabalho regular era própria ao universo malandro e não apenas pela ação repressiva das forças policiais e do Estado, mas principalmente pelas relações amorosas. $\mathrm{O}$ que as canções documentam são diversos personagens, homens e mulheres, que transitam entre a "orgia" e o "batente" por amores ou desamores, antes e depois da ascensão de Vargas e do golpe político do Estado Novo.

Além das promessas do amor e das incertezas quanto ao futuro na malandragem - a (pouca) renda obtida pela trapaça, jogos de azar etc. - a direcionar o candidato a ex-malandro rumo à regeneração, a sofrida realidade do trabalhador formal o espantava rumo à orgia. Más condições de trabalho, longas 
jornadas e péssimos salários permitiam que, aos olhos do malandro, obtendo pouco dinheiro também, mas de forma menos desgastante - "ganha-se pouco, mas é divertido", diriam Wilson Baptista e Cyro de Souza, em 1941 -, o ritmo de vida do trabalhador o tornasse um otário. Como dito, não era explicitamente de política que as canções falavam, mas de experiência vivida, o sofrido cotidiano de uma ampla parcela da população, expressa em cena pública na fala dos sambistas.

O curto livro aqui resenhado - os três capítulos contabilizam 113 páginas - serve como uma porta de entrada, um convite a um novo olhar sobre o período, atento ao cotidiano e às margens de manobra da população pobre carioca. Na vigência do Estado Novo e, particularmente, do DIP, a apologia à malandragem e a contestação aos princípios ideológicos oficiais, na forma escancarada expressa até então, eram soterrados. Porém, ainda aparecem por outras maneiras, à espera de serem descortinadas pelo faro apurado do historiador.

Resenha recebida em 14 de outubro de 2016. Aprovada em 28 de novembro de 2016. 